\title{
Intake, digestibility and ruminal parameters of dairy cows fed pelleted diets and treated with lignosulfonate-containing sunflower seeds ${ }^{1}$
}

\author{
Francilaine Eloise De Marchi ${ }^{2}$, Fábio José Ferreira Figueiroa ${ }^{2}$, Geraldo Tadeu dos Santos ${ }^{2}$, \\ Wallacy Barbacena Rosa dos Santos ${ }^{2}$, Daniele Cristina da Silva Kazama ${ }^{3}$, Antonio Ferriani \\ Branco $^{2}$, Laudí Cunha Leite ${ }^{4}$, Julio Cesar Damasceno ${ }^{2}$
}

\author{
${ }^{1}$ Project financed by Fundação Araucária and MCT-CNPq, PRONEX, 2007. \\ 2 Programa de Pós-Graduação em Zootecnia da Universidade Estadual de Maringá (UEM), Maringá, PR, Brazil. \\ ${ }^{3}$ Universidade Federal de Santa Catarina - Centro de Ciências Agrárias - Zootecnia. \\ ${ }^{4}$ Universidade Federal do Recôncavo da Bahia - Centro de Ciências Agrárias, Ambientais e Biológicas.
}

\begin{abstract}
The objective of this study was to evaluate intake, in vitro and apparent digestibility and ruminal parameters of Holstein cows that were confined and fed corn silage and concentrate containing: ground sunflower seeds (GS); ground sunflower seeds treated with 5\% lignosulfonate (GSL); pelleted sunflower seeds (PS); or ground and pelleted sunflower seeds treated with lignosulfonate (PSL). Four lactating cows with $130 \pm 28$ days of lactation and body weights of $569 \pm 63 \mathrm{~kg}$ were used. These animals were distributed in a Latin square design with four diets and four periods of 21 days each. There were no differences in the intakes (\% body weight) of dry matter (DM), organic matter (OM), mineral matter (MM), crude protein (CP), neutral detergent fiber (NDF) or acid detergent fiber (ADF). The apparent digestibility of DM, OM, CP, EE, NDF, ADF and NFC were similar for all the diets, with a tendency towards decreased CP digestibility for all the pelleted diets (65.79\%) compared with the non-pelleted diets $(69.66 \%)$. A negative effect of lignosulfonate was observed for the in vitro digestibility (IVD) of DM, and a negative tendency was observed for the IVD of OM. Pelleting decreased the concentration of acetic acid $(55.95 \times 58.82 \mathrm{mM})$ in rumen fluid. There was no effect of diet on $\mathrm{pH}(6.17)$ or ammonia nitrogen concentration $(18.19 \mathrm{mg} / \mathrm{dL})$. Pelleting and lignosulfonate do not promote the protective effect of sunflower seed nutrients as expected, and it may be more feasible to provide ground sunflower seed.
\end{abstract}

Key Words: chemical treatment, fat, heat treatment, pellet

\section{Introduction}

The composition, intake and digestibility of dietary nutrients influence the productivity of lactating dairy cows. To meet the energy demands of high-producing cows and to improve milk quality, fat sources have been added to the diet, due to the excess starch from affecting rumen functionality and to promote metabolic disorders (NRC, 2001).

However, the excess fat in ruminant feed, especially those rich in unsaturated fatty acids (UFA) such as those containing sunflower seeds, reduces the digestibility of fiber, the $\mathrm{N}-\mathrm{NH}_{3}$ concentration, and the acetate:propionate ratio. These effects result either from the toxicity of UFA against gram-positive bacteria, the physical coating of the fiber or the formation of soaps, which especially reduces the production of volatile fatty acids (VFA) (Palmquist \& Jenkins, 1980; Jenkins \& McGuire, 2006).

Upon the addition of $5.1 \%$ oil (canola oil, rice and soybeans) to the diets of goats, which consisted of a forage: concentrate ratio of $50: 50$ and $7.83 \%$ fat content, Maia et al. (2006) observed no changes in the $\mathrm{N}^{-\mathrm{NH}_{3}}$ ruminal concentrations. However, they observed an increase in the $\mathrm{pH}$, showing that addition of fat may alter ruminal fermentation patterns and microbial activity.

The oil content in sunflower seeds varies by cultivar from 20 to $45 \%$ and is comprised by $11 \%$ of saturated (SFA), $27 \%$ of mono-unsaturated (MUFA) and $60 \%$ of polyunsaturated (PUFA) fatty acids, of which $60.5 \%$ are linoleic acid (Corsini et al., 2008). Therefore, studies investigating ways to minimize the negative effects of adding high fat contents and to maximize PUFA incorporation in milk are important for improving the nutritional impact of sunflower seeds on ruminants.

Several methods, including pelleting and lignosulfonate addition, can be used to achieve these goals. The pelleting process protects nutrients from rumen microorganisms and increases the level of non-degradable proteins in the rumen (Chouinard et al., 1997). According to Petit et al. (1999), heating modifies the amino acid residues of proteins through reactions with other compounds or through cross-linking. Xylose, which is present in lignosulfonate, 
can react with several amino groups, and this reaction decreases ruminal protein degradation, thereby protecting the proteins from the activity of rumen microorganisms. Therefore, lignosulfonate and pelleting could contribute to a more gradual release of oils in the rumen, thus improving the digestibility of nutrients and the milk production of dairy cows.

Therefore, the objective of this research was to evaluate the effect of pelleting and lignosulfonate addition to sunflower seed-containing feed concentrates on intake, apparent and in vitro digestibilities and ruminal fermentation of lactating Holstein cows.

\section{Material and Methods}

The experiments were conducted at Universidade Estadual de Maringá, Maringá-PR, Brazil. To determine the effects of pelleting and lignosulphonate treatment on diet characteristics, four rumen-fistulated, multiparous Holstein cows, which averaged $569 \pm 63 \mathrm{~kg}, 130 \pm 28$ days of milk production and $17 \mathrm{~kg} /$ day of milk, were assigned to a $4 \times 4$ Latin square design with four 21 -d periods, each including 14 days for adaptation and seven days for collection.

The four mixed diets (Tables 1 and 2) consisted of supplements of ground sunflower seeds (GS), ground sunflower seeds with $50 \mathrm{~g}$ of lignosulfonate $/ \mathrm{kg}$ of sunflower DM (GSL), pelleted concentrate containing sunflower

Table 1 - Chemical composition and ingredients of the mixed diets

\begin{tabular}{|c|c|c|c|c|}
\hline & \multicolumn{4}{|c|}{ Diets } \\
\hline & GS & GSL & PS & PSL \\
\hline \multicolumn{5}{|l|}{ Chemical composition } \\
\hline Dry matter (g/kg fresh weight) & 547.5 & 545.9 & 544.7 & 544.0 \\
\hline Organic matter (g/kg DM) & 909.7 & 910.5 & 909.1 & 907.4 \\
\hline Crude protein (g/kg DM) & 181.0 & 178.4 & 177.9 & 172.7 \\
\hline Ether extract (g/kg DM) & 71.3 & 65.3 & 71.7 & 69.2 \\
\hline Neutral detergent fiber (g/kg DM) & 459.5 & 450.8 & 452.8 & 445.2 \\
\hline Acid detergent fiber (g/kg DM) & 271.5 & 268.2 & 268.8 & 265.7 \\
\hline Mineral matter (g/kg DM) & 62.4 & 62.1 & 62.6 & 63.3 \\
\hline \multicolumn{5}{|l|}{ Ingredient (g/kg DM) } \\
\hline Corn silage & 600.0 & 600.0 & 600.0 & 600.0 \\
\hline Ground corn grain & 52.7 & 52.7 & 52.7 & 52.7 \\
\hline Soybean meal & 185.8 & 185.8 & 185.8 & 185.8 \\
\hline Mineral and vitamin supplement ${ }^{1}$ & 18.0 & 18.0 & 18.0 & 18.0 \\
\hline Limestone & 10.6 & 10.6 & 10.6 & 10.6 \\
\hline Magnesium oxide & 2.8 & 2.8 & 2.8 & 2.8 \\
\hline Salt & 6.1 & 6.1 & 6.1 & 6.1 \\
\hline Sunflower seeds & 134.0 & 134.0 & 134.0 & 134.0 \\
\hline Lignosulfonate (of sunflower DM) & - & 50 & - & 50 \\
\hline \multicolumn{5}{|c|}{$\begin{array}{l}\text { GS - ground sunflower seeds; GSL - ground sunflower seeds with } 50 \mathrm{~g} \text { of } \\
\text { lignosulfonate } / \mathrm{kg} \text { of sunflower DM; PS - pelleted sunflower seeds; PSL - pelleted } \\
\text { sunflower seeds treated with } 50 \mathrm{~g} \text { of lignosulfonate } / \mathrm{kg} \text { of sunflower DM. } \\
\mathrm{DM} \text { - dry matter. } \\
{ }^{1} \mathrm{Ca}-270 \mathrm{~g} / \mathrm{kg} ; \mathrm{P}-80 \mathrm{~g} / \mathrm{kg} \text {; S - } 20 \mathrm{~g} / \mathrm{kg} ; \mathrm{Mg}-15 \mathrm{~g} / \mathrm{kg} ; \mathrm{Fe}-2,200 \mathrm{mg} / \mathrm{kg} ; \mathrm{Cu}-800 \mathrm{mg} / \mathrm{kg} \text {; } \\
\mathrm{Co}-50 \mathrm{mg} / \mathrm{kg} ; \mathrm{I}-60 \mathrm{mg} / \mathrm{kg} ; \mathrm{Se}-40 \mathrm{mg} / \mathrm{kg} \text {; Zn - } 2,800 \mathrm{mg} / \mathrm{kg} ; \mathrm{Mn}-2,680 \mathrm{mg} \text {; } \\
\text { vit. A - } 216,000 \mathrm{IU} / \mathrm{kg} \text {; vit. D - } 67,600 \mathrm{IU} / \mathrm{kg} \text {; vit. E - } 500 \mathrm{mg} / \mathrm{kg} \text {. }\end{array}$} \\
\hline
\end{tabular}

seeds (PS) and pelleted concentrate containing sunflower seeds treated with $50 \mathrm{~g}$ of lignosulfonate $/ \mathrm{kg}$ of sunflower DM (PSL).

The variety of sunflower seeds in the four concentrates was unknown and they were ground through a $5 \mathrm{~mm}$ screen. The lignosulfonate was added to the sunflower seeds after grinding and before pelleting. The corn silage:concentrate ratio was $60: 40$, meeting the $\mathrm{NRC}$ requirements for dairy cows (2001). The concentrates were mixed with the silage and offered directly in the trough.

The pelleting of the PS and PSL concentrates was accomplished with a 40 HP pelleting machine (Indústria e Comércio Chavantes Ltda, Chavantes, SP, Brazil) using a $75{ }^{\circ} \mathrm{C}$ exit temperature without adding steam. The average yield was $900 \mathrm{~kg} / \mathrm{h}$, and the screen diameter was $4.5 \mathrm{~mm}$. New batches of concentrates were produced for each of the four periods, but the same sample of ground sunflower seeds was used for the whole experiment.

The cows were housed in tie stalls, fed individually (07h15 and 16h00), and milked twice a day at 06h45 and 15h30. The cows were weighed on days 14 and 21 of each experiment period, and the dry matter intake (DMI) was expressed as a percentage of the average body weight (BW).

The provided quantities were adjusted throughout the experimental period to allow for an approximately $10 \%$ surplus in relation to the total consumed on the previous day. The samples of each total mixed ration diet were collected daily from day 15 to 20 , frozen, and pooled on a periodic basis. The composite samples were mixed thoroughly and subsampled for chemical analyses. The fecal samples of each experimental period were collected for six consecutive

Table 2 - Chemical composition and in vitro digestibility of concentrates and corn silage

\begin{tabular}{lccccc}
\hline \multirow{2}{*}{$(\mathrm{g} / \mathrm{kg})$} & \multicolumn{5}{c}{ Feed concentrates } \\
\cline { 2 - 6 } & GS & GSL & PS & PSL & CS \\
\hline DM & 913.0 & 908.8 & 906.0 & 904.2 & 305.5 \\
OM & 909.7 & 910.5 & 909.1 & 907.4 & 956.2 \\
CP & 317.1 & 310.6 & 309.3 & 296.3 & 9.03 \\
EE & 141.4 & 126.4 & 142.3 & 136.2 & 2.46 \\
NDF & 260.8 & 239.3 & 244.0 & 255.1 & 592.0 \\
ADF & 16.58 & 157.7 & 159.1 & 151.5 & 342.0 \\
MM & 90.3 & 89.5 & 90.9 & 92.6 & 43.8 \\
NFC & 190.5 & 234.3 & 213.5 & 249.8 & 250 \\
IVNDFD (g/g) & - & - & - & - & 0.687 \\
IVDMD (g/g) & - & - & - & - & 0.586 \\
IVOMD (g/g) & - & - & - & - & 0.602 \\
\hline
\end{tabular}

GS - ground sunflower seeds; GSL - ground sunflower seeds with $50 \mathrm{~g}$ of lignosulfonate/kg of sunflower DM; PS - pelleted sunflower seeds; PSL - pelleted sunflower seeds treated with $50 \mathrm{~g}$ of lignosulfonate/ $\mathrm{kg}$ of sunflower DM; CS - corn silage.

IVNDFD - in vitro neutral detergent fiber digestibility; IVDMD - in vitro dry matter digestibility; IVOMD - in vitro organic matter digestibility.

$\mathrm{NFC} \%=100-(\mathrm{CP} \%+(\mathrm{NDF} \%-\mathrm{NDF} \mathrm{cp})+\mathrm{EE} \%+\mathrm{MM} \%)(\mathrm{Hall}, 2000)$. 
days at $08 \mathrm{~h} 00,10 \mathrm{~h} 00,12 \mathrm{~h} 00,14 \mathrm{~h} 00,16 \mathrm{~h} 00$, and $18 \mathrm{~h} 00$ on days $15,16,17,18,19$, and 20 , respectively; these samples were kept frozen.

The DM of the total mixed rations, orts and feces was determined in a forced air oven according to method 934.01 (AOAC, 1990). The concentrates, silage, orts and feces were ground through a $1 \mathrm{~mm}$ screen in a Wiley mill prior to the nitrogen $(\mathrm{N})$, ether extract (EE), acid detergent fiber (ADF), and neutral detergent fiber (NDF) analyses. The total $\mathrm{N}$ content was determined following method 990.03 (AOAC, 1990). The concentrations of NDF, ADF and residual ash were measured according to the non-sequential procedures of Van Soest et al. (1991) using amylase but not sodium sulfite. Ether extractions of the diets were conducted according to method 7.060 (AOAC, 1990).

The in vitro dry matter digestibility (IVDMD) and the in vitro organic matter digestibility (IVOMD) of the four concentrates (Table 1) was determined in an Artificial Rumen (ANKON Technology ${ }^{\circledR}$, Macedon, New York, USA) using the technique described by Holden (1999). One $550 \mathrm{~kg}$ Holstein cow with a rumen fistula was used for the collection of ruminal fluid. The animal was confined and received the following diet: corn silage, ground corn, soybean meal, and a vitamin and mineral supplement. The in vitro digestibility (IVD) of the corn silage was evaluated in addition to the concentrates. The IVD was calculated as the difference between the incubated and postincubation amount of feed using the following formula: IVD $=100-[(\mathrm{W} 3-(\mathrm{W} 1 \times \mathrm{W} 4)) \times 100 / \mathrm{W} 2]$, where $\mathrm{W} 1$ is the filter weight tare; W2 is the sample weight; W3 is the filter final weight; and W4 is the correction filter blank.

The indigestible NDF was used as an internal marker to estimate the fecal output and apparent nutrient digestibility (Cochran et al., 1986). The coefficients of the apparent digestion of dietary components were determined by comparing the dietary indigestible NDF concentration (corrected for orts) with the fecal indigestible NDF concentration, as outlined by Cochran et al. (1986) and described by Neves et al. (2009).

To estimate the net energy required for lactation $\left(\mathrm{NE}_{\mathrm{L}}\right)$, the following equation was used: $\mathrm{NE}_{\mathrm{L}}(\mathrm{mcal} / \mathrm{kg})=0.0245$ $\times \%$ TDN -0.12 (NRC, 2001).

The total digestible nutrients (TDN) were estimated according to Weiss (1999): \% TDN $=\% \mathrm{DCP}+\% \mathrm{DNDF}+$ $\% \mathrm{DNFC}+\%(\mathrm{DEE} \times 2.25)$, where $\mathrm{DCP}=$ digestible crude protein; $\mathrm{DNDF}=$ digestible neutral detergent fiber; $\mathrm{DNFC}=$ digestible non-fiber carbohydrates; and $\mathrm{DEE}=$ digestible ether extract.

The non-fiber carbohydrates (NFC) of the diets were estimated using the equation proposed by Hall (2000):
$\mathrm{NFC} \%=100-(\mathrm{CP} \%+(\mathrm{NDF} \%-\mathrm{NDF} c \mathrm{~s})+\mathrm{EE} \%+\mathrm{MM} \%)$, where $\mathrm{CP}=$ crude protein; $\mathrm{NDF}=$ neutral detergent fiber; $\mathrm{NDF} c p=$ crude protein in the neutral detergent fiber; $\mathrm{EE}=$ ether extract; and $\mathrm{MM}=$ mineral matter.

To obtain representative samples, the ruminal contents were collected from the anterior dorsal, anterior ventral, medium ventral, posterior dorsal and posterior ventral regions of the rumen on the 18 th day of each period 0,2 , 4, 6 and 8 hours after the morning meal. The ruminal $\mathrm{pH}$ was monitored immediately after the sample collection with a portable pH meter (HI 931000 pHmeter, Hanna Instruments, Ronchi di Villafranca, PD, Italy). The ruminal contents were strained through four layers of cheesecloth. One $15 \mathrm{~mL}$ aliquot of filtered ruminal fluid was acidified with $0.3 \mathrm{~mL}$ of $\mathrm{H}_{2} \mathrm{SO}_{4}(0.5, \mathrm{v} / \mathrm{v})$ and frozen at $-20{ }^{\circ} \mathrm{C}$ to determine the VFA and ammonia $\mathrm{N}-\mathrm{NH}_{3}$ concentrations at a later time.

To determine the VFA concentrations, rumen fluid samples were thawed and centrifuged $(15,000 \times g$ for $50 \mathrm{~min}$ at $4{ }^{\circ} \mathrm{C}$ ), and the supernatant was analyzed according to Palmquist \& Conrad (1971). A $0.1 \mu \mathrm{L}$ aliquot was injected into a GLC (Hewlett Packard 5890 Series II GC system; Milford, MA, USA) with a $4 \mathrm{~mm}$ ID $\times 120 \mathrm{~cm}$ glass column packed with $10 \%$ Carbowax-20M/terephthalic acid on $60 / 80$ mesh acid-washed Chromabsorb W AW column packing (Supelco Inc., Bellefonte, PA, USA) and fitted with an auto sampler (Hewlett Packard 6890 Series Injector, Milford, MA, USA). The column temperature was $120^{\circ} \mathrm{C}$. Nitrogen was the carrier with a flow rate of $20 \mathrm{~mL} / \mathrm{min}$, and oxygen and air were used as detector gases with flow rates of 400 and $30 \mathrm{~mL} / \mathrm{min}$, respectively. The samples were corrected for recovery with an internal standard (2-methyl butyric). Hewlett Packard 3396 Series II software was used for chromatogram integration and analysis.

The concentration of $\mathrm{N}$ ammonia in ruminal fluid was determined by the Kjeldahl procedure (method 990.03 of AOAC, 1990) using $\mathrm{KOH}$ in place of $\mathrm{NaOH}$.

All the results were analyzed using the PROC MIXED procedure of SAS (Statistical Analysis System, version 9.0) within a $2 \times 2$ factorial arrangement of treatments. The data on in vitro digestibility were analyzed using a completely randomized design $(\mathrm{P}<0.05)$, and the remaining data were analyzed using a $4 \times 4$ Latin square design using the following general model:

$$
\mathrm{Y}_{\mathrm{ijk}}=\mu+\mathrm{A}_{\mathrm{i}}+\mathrm{P}_{\mathrm{j}}+\mathrm{T}_{\mathrm{k}}+\mathrm{e}_{\mathrm{ijk}} \text {, }
$$

where $\mathrm{Y}_{\mathrm{ijk}}=$ dependent variable; $\mu=$ overall mean; $\mathrm{A}_{\mathrm{i}}=$ effect of the animal (1, 2, 3 and 4); $P_{j}=$ effect of the period $j$ $\left(1,2,3\right.$ and 4); $T_{k}=$ effect of treatment (GS, GSL, PS, PSL); and $\mathrm{e}_{\mathrm{ijk}}=$ residual error. The treatments were compared to provide the factorial contrasts: pelleted versus non- 
pelleted, with lignosulfonate versus without lignosulfonate, and the interaction between pelleted and lignosulfonate. Significance was declared at $\mathrm{P} \leq 0.05$, and a trend was considered significant at $\mathrm{P} \leq 0.10$.

\section{Results and Discussion}

No significant differences $(\mathrm{P}>0.05)$ were observed in nutrient intake, and the average intake of the DM diets was $28.5 \mathrm{~g} / \mathrm{kg}$ body weight (Table 3 ).

The DM intake was slightly lower than expected, as the estimated DM intake for cows is approximately $18 \mathrm{~kg} /$ day (NRC, 2001). One possible explanation for this observation is the high ether content in the diets that had an average $69 \mathrm{~g} / \mathrm{kg}$ of DM. In addition, the silage used was of low quality, and it had a fiber content of $592 \mathrm{~g} / \mathrm{kg}$ of DM.

According to Van Soest (1982), high values of NDF can interfere with DM intake; values above $480-500 \mathrm{~g} / \mathrm{kg}$ of NDF reduce the silage quality and consequently decrease consumption rates. Diets with higher levels of DM, CP, NDF and EE also tend to result in reduced consumption due to an adjustment of energy intake or, when dealing only with high levels of NDF, the filling of the rumen (NRC, 2001).

Other than silage and total diet composition, heat treatment is another factor that can influence intake rates. According to the literature, pelleting improves feed palatability, reduces the selection of nutrients by the animals, destroys several microorganisms and toxic compounds and changes the feed texture. Therefore, pelleting can contribute to increased intake of several nutrients. However, this effect was not observed in the present study.
Similar to this study, Neves et al. (2007) found no significant effect of diets composed of heat-treated soybeans with or without lignosulfonate on the intake of DM, ADF and NDF. However, the authors observed a tendency towards reduced CP intake when the animals were fed diets containing heat-treated soybeans with added lignosulfonate. Likewise, Gonthier et al. (2004) used flax seeds with or without heat treatment for feeding dairy cows and did not observe any changes in dry matter intake (DMI) or organic matter intake (OMI), like in herein.

Conversely, Wright et al. (2005) fed dairy cows diets containing heat-treated oilseed meals with and without lignosulfonate and observed greater DM intake by animals fed the lignosulfonate-containing diet.

There was lower IVDMD $(0.711 \times 0.721)$ and a tendency towards lower IVOMD $(0.716 \times 0.727 ; \mathrm{P}<0.10)$ in the concentrates treated with lignosulfonate (Table 4). However, there was no interaction effect between the lignosulfonate addition and the pelleting process. Bett et al. (2004) evaluated IVDMD, in vitro crude protein digestibility (IVCPD) and the in vitro digestibility of ether extract (IVEED) of sunflower seeds, whole or broken, of three different varieties and found values between 0.529 and $0.611 \mathrm{~g} / \mathrm{g}$ for IVDMD, 0.916 and $0.945 \mathrm{~g} / \mathrm{g}$ for IVCPD and 0.587 and $0.719 \mathrm{~g} / \mathrm{g}$ for IVEED.

Among the properties of lignosulfonate, Melbar (2000) highlights surfactants, binders, dispersants, emulsifiers, sequestrants, palatability and its potential to be combined with proteins. In the animal food industry, calcium and magnesium lignosulphonates are used in a pellet agglutinant. Petit et al. (1999) utilized full-fat soybeans and

Table 3 - Nutrient intake $(\mathrm{kg} /$ day and $\%$ of BW) of dairy cows

\begin{tabular}{|c|c|c|c|c|c|c|c|c|}
\hline & \multicolumn{4}{|c|}{ Diets } & \multirow{2}{*}{ SE } & \multicolumn{3}{|c|}{ Probability } \\
\hline & GS & GSL & PS & PSL & & $\mathrm{L}$ & $\mathrm{P}$ & I \\
\hline \multicolumn{9}{|c|}{ Total diet intake (kg/day) } \\
\hline Dry matter & 15.50 & 16.35 & 16.25 & 15.64 & 2.04 & 0.96 & 1.00 & 0.73 \\
\hline Organic matter & 14.51 & 15.31 & 15.23 & 14.64 & 1.91 & 0.96 & 0.99 & 0.72 \\
\hline Mineral matter & 1.00 & 1.03 & 1.02 & 0.99 & 0.13 & 0.98 & 0.96 & 0.78 \\
\hline Crude protein & 2.94 & 3.02 & 2.98 & 2.76 & 0.36 & 0.84 & 0.76 & 0.68 \\
\hline Ether extract & 1.19 & 1.14 & 1.22 & 1.15 & 0.14 & 0.65 & 0.89 & 0.96 \\
\hline Neutral detergent fiber & 6.75 & 7.07 & 7.10 & 6.75 & 1.01 & 0.99 & 0.99 & 0.75 \\
\hline Acid detergent fiber & 4.00 & 4.12 & 4.25 & 4.06 & 0.57 & 0.95 & 0.87 & 0.80 \\
\hline \multicolumn{9}{|c|}{ Total intake $(\mathrm{g} / \mathrm{kg}$ of $\mathrm{BW})$} \\
\hline Dry matter & 28.29 & 28.99 & 29.18 & 27.30 & 0.44 & 0.90 & 0.93 & 0.78 \\
\hline Organic matter & 26.23 & 27.89 & 27.18 & 25.43 & 0.41 & 0.90 & 0.93 & 0.77 \\
\hline Mineral matter & 1.82 & 1.84 & 1.84 & 1.72 & 0.03 & 0.87 & 0.86 & 0.82 \\
\hline Crude protein & 5.36 & 5.35 & 5.37 & 4.81 & 0.08 & 0.73 & 0.75 & 0.74 \\
\hline Ether extract & 2.18 & 2.02 & 2.20 & 2.00 & 0.03 & 0.58 & 0.99 & 0.96 \\
\hline Neutral detergent fiber & 12.35 & 12.55 & 12.76 & 11.78 & 0.21 & 0.86 & 0.93 & 0.79 \\
\hline Acid detergent fiber & 7.30 & 7.30 & 7.65 & 7.08 & 0.12 & 0.82 & 0.96 & 0.82 \\
\hline
\end{tabular}

SE - standard error; BW - body weight; GS - ground sunflower seeds; GSL - ground sunflower seeds with 50 g of lignosulfonate/kg of sunflower DM; PS - pelleted sunflower seeds PSL - pelleted sunflower seeds treated with $50 \mathrm{~g}$ of lignosulfonate $/ \mathrm{kg}$ of sunflower DM.

$\mathrm{L}$ - lignosulfonate effect; $\mathrm{P}$ - pelleted effect; I - interaction effect $(\mathrm{P}<0.05)$. 
lignosulfonate and found that the lignosulfonate reduced the ruminal degradation of grain proteins, thus increasing the levels ruminal non-degradable proteins by protecting them from the activity of rumen microorganisms; the authors also observed a decrease in DM digestibility upon increased temperature and the addition of lignosulfonate.

Windschitl \& Stern (1988) observed a decrease in organic matter digestibility when $5 \%$ lignosulfonate was added to soybean meal. Dos Santos et al. (2011) also worked with pelleted and lignosulfonate in sunflower seeds and observed that lignosulfonate and pelleting had no effect on the digestibility of DM. However, various methods were used to measure digestibility, and the temperature in each heat treatment method was variable, providing a possible explanation for the differing responses to lignosulfonate between experiments.

There were no significant differences $(\mathrm{P}>0.05)$ in the total apparent digestibility of DM, OM, CP, EE, NDF and ADF of diets (Table 5). However, there was a tendency $(\mathrm{P}<0.10)$ towards lower digestibility of the $\mathrm{CP}$ with the pelleted $(0.658 \mathrm{~g} / \mathrm{g})$ compared with non-pelleted treatments $(0.697 \mathrm{~g} / \mathrm{g})$. The low apparent DM digestibility of the total diets was also observed. This was possibly due to the poor quality and high fiber levels of the corn silage, which had a high NDF content $(0.592 \mathrm{~g} / \mathrm{g})$, low IVDMD $(0.586 \mathrm{~g} / \mathrm{g})$ and non-ideal particle size.

Wang et al. (1999) reported that thermal treatment of oilseed diets changes the location of protein digestion from within the rumen to the intestine with little effect on total digestibility. According to Whitlock et al. (2002), food processing techniques can be used to improve animal diets with regards to content and the use of dietary nutrients. It was expected that pelleting would increase the total digestible CP simply by changing the location of degradation from inside the rumen to the small intestine, causing it to be better utilized by animals. However, pelleting did not show the expected effect in the present study because it tended to reduce the total digestible $\mathrm{CP}$.

O'Doherty et al. (2000) reported that various functions are derived from pelleting, including the improvement of $\mathrm{OM}$ digestibility, energy, ash and $\mathrm{CP}$, which were not observed in this work. However, it is known that high temperatures denature and alter the solubility of proteins. The temperature during the pelleting process is high at approximately $93{ }^{\circ} \mathrm{C}$, and such heating may influence the digestibility of pelleted $\mathrm{CP}$ treatments by altering the protein structure, thus exposing hydrophobic amino acids to the molecular surface and causing a drop in solubility. Therefore, the pelleting treatment may have caused a reduction in the rate of ruminal fermentation or protein absorption.

Neves et al. (2009) obtained results with canola seeds that differed from those obtained in this work. They observed reductions in the DM, OM and NFC digestibilities when the treatments contained lignosulfonate compared to the treatments without lignosulfonate. However, they found no difference between the digestibilities of extruded or nonextruded DM, OM, CP, EE, NDF, ADF and NFC treatments with lignosulfonate.

Gonthier et al. (2004) reported that the use of flax seeds subjected to heat treatment, micronization and extrusion

Table 4 - In vitro digestibility of dry matter (IVDMD) and organic matter (IVOMD) of concentrates

\begin{tabular}{|c|c|c|c|c|c|c|c|c|}
\hline \multirow{2}{*}{$(\mathrm{g} / \mathrm{kg})$} & \multicolumn{4}{|c|}{ Diets } & \multirow{2}{*}{ SE } & \multicolumn{3}{|c|}{ Probability } \\
\hline & GS & GSL & PS & PSL & & $\mathrm{L}$ & $\mathrm{P}$ & I \\
\hline IVDMD (g/g) & 0.737 & 0.703 & 0.723 & 0.718 & 0.87 & 0.05 & 0.94 & 0.12 \\
\hline IVOMD (g/g) & 0.742 & 0.708 & 0.730 & 0.725 & 0.83 & 0.06 & 0.91 & 0.1 \\
\hline
\end{tabular}

SE - standard error; GS - ground sunflower seeds; GSL - ground sunflower seeds with $50 \mathrm{~g}$ of lignosulfonate/kg of sunflower DM; PS - pelleted sunflower seeds; PSL - pelleted sunflower seeds treated with $50 \mathrm{~g}$ of lignosulfonate $/ \mathrm{kg}$ of sunflower DM.

$\mathrm{L}$ - lignosulfonate effect; $\mathrm{P}$ - pelleted effect; $\mathrm{I}$ - interaction effect $(\mathrm{P}<0.05)$.

Table 5 - Apparent nutrient digestibility by dairy cows

\begin{tabular}{|c|c|c|c|c|c|c|c|c|}
\hline \multirow{2}{*}{ Digestibility (g/kg) } & \multicolumn{4}{|c|}{ Diets } & \multirow{2}{*}{ SE } & \multicolumn{3}{|c|}{ Probability } \\
\hline & GS & GSL & PS & PSL & & $\mathrm{L}$ & $\mathrm{P}$ & I \\
\hline Dry matter & 558.4 & 565.2 & 531.8 & 556.3 & 2.47 & 0.54 & 0.49 & 0.73 \\
\hline Organic matter & 580.5 & 593.3 & 562.0 & 582.6 & 2.48 & 0.52 & 0.57 & 0.88 \\
\hline Ether extract & 947.7 & 945.3 & 937.9 & 943.8 & 0.58 & 0.77 & 0.35 & 0.49 \\
\hline Neutral detergent fiber & 383.8 & 392.0 & 346.8 & 361.5 & 3.95 & 0.78 & 0.42 & 0.94 \\
\hline Acid detergent fiber & 318.8 & 305.0 & 317.8 & 342 & 4.44 & 0.54 & 0.49 & 0.73 \\
\hline
\end{tabular}

SE - standard error; GS - ground sunflower seeds; GSL - ground sunflower seeds with 50 g of lignosulfonate/kg of sunflower DM; PS - pelleted sunflower seeds; PSL - pelleted sunflower seeds treated with $50 \mathrm{~g}$ of lignosulfonate $/ \mathrm{kg}$ of sunflower DM.

L - lignosulfonate effect; $\mathrm{P}$ - pelleted effect; I - interaction effect $(\mathrm{P}<0.05)$. 
did not affect the total digestibility of DM and OM, which is consistent with the observations in this study.

Comparing the in vitro digestibility (Table 4) and total apparent digestibility (Table 5) results of the various concentrates, it can be noted that there was a lower apparent digestibility of DM $(0.553 \mathrm{~g} / \mathrm{g})$ and OM $(0.580 \mathrm{~g} / \mathrm{g})$ compared with IVDMD $(0.721 \mathrm{~g} / \mathrm{g})$ and IVDOM $(0.726 \mathrm{~g} / \mathrm{g})$. This difference was expected due to the absence of the passage rate effect, which is higher in dairy cows, thus providing less time for nutrient digestion as compared with the in vitro model. In addition, endogenous metabolic compounds were absent in the in vitro studies but were present in the feces.

The pelleting and lignosulfonate addition did not change the concentrations of net energy for lactation $\left(\mathrm{NE}_{\mathrm{L}}\right)$ and total digestible nutrients (TDN) (Table 6). However, the non-fiber carbohydrates (NFC) of diets, as estimated by their differences, was amended by pelleting $(\mathrm{P}<0.05)$. The TDN is dependent on diet composition, consumption and digestibility. Therefore, given the lack of an effect of heat treatment on pelleting and the chemical treatment with lignosulfonate, the TDN results were as expected. The same is true for the $\mathrm{NE}_{\mathrm{L}}$, which is dependent on the diet composition (CP, NDF, EE, MM and TDN).

The use of pelleting increased the NFC content in the concentrates. The NFC group consists of starches and sugars, which are present in the cell and are readily available energy sources. Pelleting may have increased the NFC content by affecting the interaction between the protein matrix and the starch granules and/or increasing the solubility of starch. Therefore, a higher NFC digestibility was expected; however, this was not observed. A possible explanation for these results is the occurrence of the Maillard reaction, where the protein binds with the carbohydrate, which could explain the tendency observed for the decreased $\mathrm{CP}$ digestibility on the pelleted treatments.

As regards the volatile fatty acid (VFA) concentrations, there was a significant effect of pelleting on the concentration of acetic acid; the concentration was lower in the pelleted (55.95 $\mathrm{mM})$ compared with the non-pelleted diets $(58.82 \mathrm{mM})$ (Table 7). There was no effect of the treatments on the levels of other VFA, ammonia nitrogen or $\mathrm{pH}$.

The VFA results in this study corroborate the findings of Dos Santos et al. (2011), who assessed the effect of supplying sunflower seeds with or without pelleting or lignosulfonate to the diet of dairy cows. The authors observed that pelleting and/or the addition of lignosulfonate generally did not affect the VFA concentration. The one exception was that the acetic acid concentration was reduced by pelleting. One hypothesis raised by the authors is that pelleting released more oil, and the same may have occurred in this study.

Diets high in carbohydrates (seeds) favor the formation of higher propionic acid levels, while those rich in protein, butyric acid and roughage (fiber) favor acetic acid (Valadares Filho \& Pina, 2006). Therefore, two main factors may

Table 6 - Total digestible nutrient (TDN), net energy for lactation (NEL) and non-fiber carbohydrates (NFC) of diets

\begin{tabular}{|c|c|c|c|c|c|c|c|c|}
\hline & & & & & $\mathrm{CL}$ & & obabil & \\
\hline & GS & GSL & PS & PSL & & $\mathrm{L}$ & $\mathrm{P}$ & I \\
\hline TDN (g/kg) & 618.6 & 603.3 & 626.6 & 620.2 & 2.3 & 0.60 & 0.65 & 0.85 \\
\hline NEL (Mcal/kg DM) & 1.40 & 1.36 & 1.42 & 1.40 & 0.06 & 0.60 & 0.65 & 0.85 \\
\hline $\mathrm{NFC}(\mathrm{g} / \mathrm{kg})$ & 225.8 & 235.0 & 243.4 & 249.6 & 0.47 & 0.01 & 0.14 & 0.75 \\
\hline
\end{tabular}

SE - standard error; GS - ground sunflower seeds; GSL - ground sunflower seeds with $50 \mathrm{~g}$ of lignosulfonate/kg of sunflower DM; PS - pelleted sunflower seeds; PSL - pelleted sunflower seeds treated with $50 \mathrm{~g}$ of lignosulfonate $/ \mathrm{kg}$ of sunflower DM.

L - lignosulfonate effect; $\mathrm{P}$ - pelleted effect; I - interaction effect $(\mathrm{P}<0.05)$.

Table 7 - Volatile fatty acid (VFA) and ammonia nitrogen $\left(\mathrm{N}-\mathrm{NH}_{3}\right)$ concentrations and $\mathrm{pH}$ values

\begin{tabular}{|c|c|c|c|c|c|c|c|c|}
\hline \multirow{2}{*}{$\mathrm{mM} / \mathrm{dL}$} & \multicolumn{4}{|c|}{ Diets } & \multirow{2}{*}{ SE } & \multicolumn{3}{|c|}{ Probability } \\
\hline & GS & GSL & PS & PSL & & $\mathrm{L}$ & $\mathrm{P}$ & $\mathrm{I}$ \\
\hline Acetic acid & 54.81 & 55.51 & 62.83 & 56.39 & 2.11 & 0.05 & 0.11 & 0.19 \\
\hline Propionic acid & 29.39 & 33.45 & 27.5 & 24.77 & 5.26 & 0.33 & 0.53 & 0.9 \\
\hline Valeric acid & 1.97 & 1.97 & 1.65 & 1.84 & 0.23 & 0.34 & 0.7 & 0.68 \\
\hline Iso-butyric acid & 1.09 & 1.15 & 1.87 & 1.38 & 0.38 & 0.20 & 0.47 & 0.58 \\
\hline Iso-valeric acid & 2.43 & 2.6 & 2.43 & 2.39 & 0.23 & 0.66 & 0.67 & 0.78 \\
\hline $\mathrm{N}^{-\mathrm{NH}_{3}}(\mathrm{mg} / \mathrm{dL})$ & 19.13 & 17.78 & 18.1 & 17.73 & 2.22 & 0.81 & 0.71 & 0.83 \\
\hline $\mathrm{pH}$ & 6.11 & 6.26 & 6.25 & 6.06 & 0.16 & 0.87 & 0.89 & 0.30 \\
\hline
\end{tabular}

SE - standard error; GS - ground sunflower seeds; GSL - ground sunflower seeds with $50 \mathrm{~g}$ of lignosulfonate/kg of sunflower DM; PS - pelleted sunflower seeds or PSL - pelleted sunflower seeds treated with $50 \mathrm{~g}$ of lignosulfonate $/ \mathrm{kg}$ sunflower DM.

L - lignosulfonate effect; $\mathrm{P}$ - pelleted effect; I - interaction effect $(\mathrm{P}<0.05)$. 
contribute to reducing the levels of acetic acid: high levels of carbohydrates and high levels of fats. The use of lipids in the diet can interfere with ruminal fermentation, especially when the inclusion values exceed $7.0 \%$ of the nutrients, thus compromising fiber digestion and, consequently, acetate production (Palmquist, 1989; Jenkins, 1993).

The treatments did not affect $(\mathrm{P}>0.05)$ the $\mathrm{pH}$ or the ammonia nitrogen concentration (Table 7). Dos Santos et al. (2011) observed different results from those found in the present study. Their group reported a higher ruminal $\mathrm{pH}$ in dairy cows fed pelleted concentrates when compared with non-pelleted concentrates. The authors stated that the higher $\mathrm{pH}$ may have occurred because the pellet released a greater amount of fat in the rumen, which was related to the anti-protozoal effect of the linoleic acid present in sunflower seeds, as noted by Ivan et al. (2003).

The presence of ammonia nitrogen in ruminal fluid is a major factor in the development of the rumen microbiota, which influences the $\mathrm{pH}$ and, thus, ruminal fermentation. The use of pelleting or lignosulfonate did not reduce the effects of sunflower seed-derived fats on the rumen because there was no difference between the protected diets and the ground seed (GS) diet.

The average values of $\mathrm{pH}$ and ammonia nitrogen concentrations in this study were 6.17 and $18.19 \mathrm{mg} / \mathrm{dL}$, respectively. The average $\mathrm{pH}$ values were within the limits recommended by Van Soest (1994). Furthermore, the 5.5 to 7.0 for the proper rumen and ammonia nitrogen concentration, respectively, met the minimum amount that was recommended by Lana (2005) and was within the recommendations by Leng \& Nolan (1984).

The diets used in this study had CP values above the NRC (2001) recommendations for the animal category used. However, despite the high level of crude protein in the diet, there was no excess of ruminal ammonia, which may be due to the high availability of ruminal carbohydrates. Another possible contributing factor was the low intake of the diets.

The fact that the ammonia nitrogen concentrations did not differ between treatments suggests that the processing methods employed in this work were not effective in protecting the protein. This differs from the results obtained by Wright et al. (2005), who found a reduction in the ammonia nitrogen concentration using lignosulfonate, and Wernersbach Filho et al. (2006), who observed a reduction in the ammonia nitrogen concentration in animals fed extruded diets. It is likely that either all diets provided sufficient energy for the use of protein, or the pellet did not affect the ruminal rate of carbohydrate degradation as expected.
Unlike the present study, Loor et al. (2002) observed higher ruminal $\mathrm{pH}$ levels when the dairy cow diet was supplemented with protected fat sources than with canola oil. Furthermore, the ammonia nitrogen concentration decreased in response to lipid supplementation and was lower in protected sources.

Working with ground or extruded canola seeds with or without lignosulfonate, Neves et al. (2009) also observed no change in ruminal parameters.

\section{Conclusions}

Neither treatments (pelleting and lignosulfonate) influences diet intake, ruminal parameters or nutrient digestibility. Lignosulfonate has a negative effect on in vitro dry matter digestibility. The use of both treatments is dispensable in diets containing sunflower seeds, and it is only necessary to supply the ground seeds.

\section{References}

ASSOCIATION OF OFFICIAL AGRICULTURAL CHEMISTS AOAC. Official methods of analysis. 15.ed. Washington, D.C.: AOAC, 1990

BETT, V.; SILVA, L.D.F. Girassol na dieta de ruminantes. In: LEITE, R.M.V.B.C.; BRIGHENTI, A.M.; CASTRO, C. (Eds.). Girassol no Brasil. Londrina: Embrapa Soja, 2004. p.69-92.

CHOUINARD, P.Y.; LÉVESQUE, J.; GIRARD, V. et al. Performance and profiles of milk fatty acids of cows fed full fat, heat-treated soybeans using various processing methods. Journal of Dairy Science, v.80, p.334-342, 1997.

COCHRAN, R.C.; ADAMS, D.C.; WALLACE, J.D. et al. Predicting digestibility of different diets with internal markers: Evaluation of four potential markers. Journal Animal Science, v.63, p.1476-1483, 1986.

CORSINI, M.S.; JORGE, N.; RAUEN, A.M. et al. Perfil de ácidos graxos e avaliação da alteração em óleos de fritura. Química Nova, v.31, p.956-961, 2008.

DOS SANTOS, W.B.R.; SANTOS, G.T.D.; SILVA-KAZAMA, D.C. et al Production performance and milk composition of grazing dairy cows fed pelleted or non-pelleted concentrates treated with or without lignosulfonate and containing ground sunflower seeds. Animal Feed Science and Technology, v.169, p.167-175, 2011.

GONTHIER, C.; MUSTAFA, A.F.; BERTHIAUME, R. et al. Effects of feeding micronized and extruded flaxseed on ruminal fermentation and nutrient utilization by dairy cows. Journal of Dairy Science, v.87, p.1854-1863, 2004.

HALL, M.B. Neutral detergent-soluble carbohydrates nutritional relevance and analysis. Florida: Institute of Food and Agricultural Sciences, University of Florida, 2000. 42p.

HOLDEN, L.A. Comparison of methods of digestibility for ten feeds. Journal of Dairy Science, v.82, p.1791-1794, 1999.

IVAN, M.; ENTZ, T.; MIR, P.S. et al. Effects of sunflower seed supplementation and different dietary protein concentrations on the ciliate protozoa population dynamics in the rumen of sheep. Canadian Journal of Animal Science, v.83, p.809-817, 2003.

JENKINS, T.C. Lipid metabolism in the rumen. Journal of Dairy Science, v.76, p.3851-3863, 1993. 
JENKINS, T.C.; McGUIRE, M.A. Major advances in nutrition: impact on milk composition. Journal of Dairy Science, v.89, p.1302-1310, 2006.

LANA, R.P. Nutrição e alimentação animal (mitos e realidades). Viçosa, MG: UFV, 2005. 344p.

LENG, R.A.; NOLAN, V. Nitrogen metabolism in the rumen. Journal of Animal Science, v.67, p.1072-1075, 1984.

LOOR, J.J.; HERBEIN, J.H.; JENKINS, T.C. Nutrient digestion, biohydrogenation and fatty acid profiles in blood plasma and milk fat from lctating Holstein cows fed canola oil or canolamide. Animal Feed Science and Technology, v.97, p.65-82, 2002.

MAIA, F.J.; BRANCO, A.F.; MOURO, G.F. et al. Inclusão de fontes de óleo na dieta de cabras em lactação: digestibilidade dos nutrientes e parâmetros ruminais e sanguíneos. Revista Brasileira de Zootecnia, v.35, p.1496-1503, 2006.

MELBAR. Lignosulphonate. São Paulo. [catálogo], 2000. 22p.

NATIONAL RESEARCH COUNCIL - NRC. Nutrient requirements of dairy cattle. 7. rev. ed. Washington, D.C.: National Academy of Sciences, 2001. 381p.

NEVES, C.A.; SANTOS, G.T.; MATSUSHITA, M. et al. Intake, digestibility, milk production, and milk composition of Holstein cows fed extruded soybeans treated with lignosulphonate. Animal Feed Science and Technology, v.134, p.32-44, 2007.

NEVES, C.A.; DOS SANTOS, W.B.R.; SANTOS, G.T. et al. Production performance and milk composition of dairy cows fed extrused canola seeds treated with or without lignosulphonate. Animal Feed Science and Technology, v.154, p.83-92, 2009.

O'DOHERTY, J.V.; MACGLYNN, S.G.; MURPHY, D. The effect of expander processing and pelleting on nutritive value of feed for growing and finishing pigs. Journal of the Science of Food and Agriculture, v.81, p.135-141, 2000.

PALMIQUIST, D.; CONRAD, H. Origin of plasma fatty acids in lactating cows fed high fat diets. Journal of Dairy Science, v.74, p.3152, 1971.

PALMQUIST, D.L.; JENKINS, T.C. Fat in lactation rations: review. Journal of Dairy Science, v.63, p.1-14, 1980.

PALMQUIST, D.L. Suplementação de lipídios para vacas em lactação. In: SIMPÓSIO SOBRE NUTRIÇÃO DE RUMINANTES, 6., 1989, Piracicaba. Anais... Piracicaba: FEALQ, 1989. p.11.
PETIT, H.V.; TURCOTTE, M.; AUDY, R. Degradability and digestibility of full-fat soybeans treated with different sugar and heat combinations. Canadian Journal of Animal Science, v.79, p.213-220, 1999.

VALADARES FILHO, S.C.; PINA, D.S. Fermentação ruminal. In: BERQUIELLI, T.T.; PIRES, A.V.; OLIVEIRA, S.G. (Eds.) Nutrição de ruminantes. Jaboticabal: Funep, 2006. p.151-182.

VAN SOEST, P.J. Nutritional ecology of the ruminant. Ithaca: Cornell University Press, 1982. 373p.

VAN SOEST, P.J.; ROBERTSON, J.B. et al. Methods for dietary fiber, neutral detergent fiber, and nonstarch polysaccharides in relation to animal nutrition. Journal of Dairy Science, v.74, p.3583-3598, 1991.

VAN SOEST, P.J. Nutritional ecology of the ruminant. 2.ed. New York: Cornell University Press, 1994. 476p.

WANG, Y.; McALLISTER, T.A.; PICKARD, M.D. et al. Effect of micronization full fat canola seed on amino acid disappearance in gastrointestinal tract on dairy cows. Journal of Dairy Science, v.82, p.537-544, 1999.

WEISS, W. Energy prediction equations for ruminant feeds. In: CORNEL NUTRITION CONFERENCE FOR FEED MANUFACTURERS, 61., 1999, Ithaca. Proceedings... Ithaca: Cornell University, 1999. p.176-185.

WERNERSBACH FILHO, H.L.; CAMPOS, J.M.S.; ASSIS, A.J. et al. Variáveis ruminais, concentração de uréia plasmática e excreções urinárias de nitrogênio em vacas leiteiras alimentadas com concentrado processado de diferentes formas. Revista Brasileira de Zootecnia, v.35, p.1236-1241, 2006.

WHITLOCK, L.A.; SCHINGOETHE, D.J.; HIPPEN, A.R. et al. Fish oil and extruded soybeans fed en combination increase conjugated linoleic acids in milk of dairy cows more than when fed separately. Journal of Dairy Science, v.85, p.234-243, 2002.

WINDSCHITL, P.M.; STERN, M.D. Evaluation of calcium lignosulfonate-treated soybean meal as a source of rumen protected protein for dairy cattle. Journal of Dairy Science, v.71, p. 3310-3322, 1988.

WRIGHT, C.F.; KEYSERLINGK, A.G.; SWIFT, M.L., et al. Heat and lignosulfonate treated canola meal as a source of ruminal undegradable protein for lactating dairy cows. Journal of Dairy Science, v.88, p.238-243, 2005. 